Indonesian Journal of EFL and Linguistics

Vol. 2 No. 2, 2017

eISSN: 2503-4197, pISSN: 2527-5070

www. indonesian-efl-journal.org

\title{
Exploring Students Use of Facebook in Formal Learning Contexts
}

\author{
Nagaletchimee Annamalai \\ School of Distance Education, Universiti Sains Malaysia \\ e-mail: naga@usm.my
}

\begin{abstract}
:
This qualitative study aims to explore the use of Facebook environment in narrative writing. Data were collected from students' narrative writing and focus group interview. The essays were analysed based on Spandel Assessment Scale (2005).The findings revealed that eventhough students improved their narrative writing, there was lack of in-depth discussion to construct knowledge. It further proposed that teacher needs to facilitate and guide students as time, space and resources are available online. The students indicated that Facebook was beneficial as it was a convenient and engaging writing platform. Students also pointed the availability of web-resources to enhance their writing.There were more positive experiences and fewer negative experiences. Limitations of the study were also discussed along with suggestions for future research.
\end{abstract}

Keywords: social networking sites, Facebook, social interactions, collaboration, writing skill 


\section{INTRODUCTION}

Technological revolution in the past two decades has created profound implications for the use of technologies in schools (Sweeny, 2010). According to Mehlinger and Powers (2002), Information and Communication Technology (ICT) "will have, is having, has had, can have an impact on how we teach and learn" (p. 11). Schools are internationally faced with the demands to integrate ICT in educational policies, curriculum and classroom practices. In this sense, ICT has caused tremendous challenges for educators to depart from the traditional teaching approaches to embrace new approaches to add value and fulfil the demand of the new generation (Lin et al., 2013).

A variety of tools have been integrated in schools and higher education and can be classified according to its temporal nature, either synchronous or asynchronous. These tools can also be classified as either freely available (open source materials) and for commercial purposes. Some of the freely available tools are blogs, wikis, discussion boards, e-mails and Facebook and commercially online tools are Babylon, Master Writer, eXpert Communicator and StyleWriter Professional (BrotherSoft, 2012). In the face of costly commercially available writing tools, especially when it is a problem for schools, a welcoming invitation would be innovative use of these freely available open source tools.

An obvious social networking site that is freely available and can be manipulated for education context is Facebook. Research have supported the positive impact of Facebook in educational context (McCarthy, 2015; Shih, 2011; Bosch, 2009). It has allowed the shift from learner-centred to teacher-centred education (Lee at al.2009) and increased the efficiency of flexible accessibility, convenience and cost (Cantoni, Cellario \& Porta, 2004). More advanced application of the Facebook environment would be the availability of recent educational resources and digital materials (Sahin \& Ukuyol, 2016).

Facebook contains many features that can be used in teaching and learning activities. For example, Like, Chatroom, Comments, Notifications, Messages, News Feed, Events, Groups, Apps, Friends and etc. To use Facebook and to achieve positive learning outcomes, one need not necessarily utilized all the features. Only certain features need to be used to accomplish the task planned.

The current study serves to extend research related to Facebook by examining the quality of the students writing after they were engaged in the social interactions in their collaborative learning in the Facebook environment. In this study, the researcher intends to use Groups, Comments and Walls. To the best of the researchers' knowledge, no attention has been paid to the narrative writing skill and the experiences of the ESL learners in the Facebook environment in the Malaysian secondary school context.Teaching of writing in the Malaysian classroom is limited due to time and space (Darus \& Ching 2009). It is suggested that online writing environment such as Facebook allows flexibility and students will be able to work on their own pace. Therefore, Facebook environment is used to encourage narrative writing among students. 
The research question that guided these studies were:

\subsection{Research Question}

1. Do the teaching and learning activities in the Facebook environment improve students' narrative writing?

2. What are the reasons that may explain the changes or lack thereof?

\section{LITERATURE REVIEW}

Facebook has obviously becoming ubiquitous in formal as well as in non-formal learning. Since Facebook was not typically designed for educational context, the appropriate approach and pedagogical practices play a crucial role in influencing the potential of the Facebook environment in teaching and learning activities (Hamid et al., 2014). Studies have shown that when Facebook is infused with appropriate pedagogical repertoire, positive learning outcomes can be achieved. O'Bannon (2013) found that Facebook was considered by the pre-service teachers as a source of learning that was convenient, enhances learning and provides a good means of communication. Razak \& Saeed (2014) investigated revision strategies among EFL(English as a foreign language) learners in Facebook. The study found that Community of Practice $(\mathrm{CoP})$ facilitated students provided an environment for greater learning, increased willingness to interact and eventually developed a sense of independence among them learners to improve their writing.

Buga et al. (2014) discovered that when Facebook was used as a platform for home assignments with a group of French students and another group with English students, students who were never keen to do their homework before, started responding and showed interest to complete their assignments. They concluded that Facebook used as an educational platform in a foreign language class has encouraged genuine communication. Pimmer et al.(2015) also drew many positive outcomes from the medical students as well as the faculty when used Facebook to discuss medical and clinical topics. They also found that quizzes, case presentations and deliberate e-learning practices which are often found in formal educational settings were applicable in the Facebook environment. Joel (2015) observed the Botswana students' interest in the use of Facebook for the oral presentation. The study reported that $80 \%$ of the students opted for Facebook and $20 \%$ chose to do their oral presentation traditionally. Basically, Facebook's popularity, interactive and collaborative features make it an appropriate site for online learning. It inherits some of the highly sought after qualities that are effective and long have been practiced in traditional classroom and higher learning. In fact Staines \& Lauchs, (2013) pointed out that Facebook should be viewed as learners' normal extension and part of their daily life practice.

Nevertheless, it is also pertinent to look at the deficiencies in pedagogical and technical aspects. Studies have also revealed that Facebook is not positively correlated with teaching and learning activities. According to Hew (2011) Facebook does not play a crucial role in education and Kwan and Skoric (2013) opine that Facebook created the opportunity for bullying and victimization to occur in the 
Facebook environment. Further, Selyn (2009) found that students were not consistent in exchanging academic information in Facebook. Students' discussion was focused on matters related to assessments and course readings rather than engaging in in-depth discussion on course tasks. Similar findings were also confirmed by Madge et al. (2009) who found that students were not enthusiastic on using Facebook for formal educational settings. Underpinning much of the discussion of the negative effects of Facebook is the realization that it is not solely meant for educational context (McCarty, 2013). Some of the negative effects of Facebook can be addressed if appropriate approach is used. In fact, Kent and Leave (2014) aptly said that "Facebook is not a singular tool, but a wide ranging set of tools and practices tied together in an online platform. Different uses of this platform will inevitably lead to different outcomes..." (p.61).

Obviously, different pedagogical practices and different geographical and sociocultural environment plays a fundamental role in allowing or obfuscates the use of Facebook as an educational tool. Researches have also called for more studies related to Facebook (Manca \& Ranieri, 2013). Thus, more research is needed to determine the appropriate use of Facebook in different context. It is for this reason, this study is undertaken to look into the quality of students' writing and students' experiences when Facebook is used as an online writing platform. Studies also highlighted those students' experiences of writing also impacts students' quality of writing. Thus, this study intends to investigate students' experience to assist teachers to determine the best pedagogical practices when integrating ICT tools instead of perpetuating negative teaching practices.

\section{RESEARCH METHODOLOGY}

The current study employed a qualitative case study. A qualitative case study is an "intensive holistic description and analysis of a bounded phenomenon" (Merriam, 1998 , p. xiii). It is a systematic procedure that considers step by step progression and various precautions to enhance rigor, validity and reliability to provide rich and meaningful data that the researcher can report with confidence. Four important criteria for naturalistic research suggested by Lincoln and Cuba(1985) have been considered in this study. Table 1 demonstrates the link.

Table 1

Lincoln and Cuba's Translation of Terms

\begin{tabular}{lll}
\hline $\begin{array}{l}\text { Conventional } \\
\text { Inquiry }\end{array}$ & $\begin{array}{l}\text { Naturalistic } \\
\text { Inquiry }\end{array}$ & Methods to ensure quality \\
\hline Internal Validity & Credibility & $\begin{array}{l}\text { Member check; prolonged engagement in the } \\
\text { field; data triangulation; researcher do not } \\
\text { distort information }\end{array}$ \\
\hline External Validity & Transferability & Thick description of setting or participants \\
\hline Reliability & Dependability & $\begin{array}{l}\text { Audit-researcher's documentation of data, } \\
\text { methods and decisions; researcher } \\
\text { triangulation }\end{array}$ \\
\hline Objectivity & Confirmability & Audit and reflexivity \\
\hline
\end{tabular}

Source: Lincoln and Guba (1985) 


\subsection{Participants}

Six ESL students and a teacher were invited to participate in this study. Their names were changed to maintain confidentiality. The participants were Year 10 class located in an urban school in northern region of Malaysia. Purposive sampling was employed in this study and the students were selected based on their Year 9 standardised public examination, Penilaian Menengah Rendah (PMR).Three participants were from the advanced group and another three students were from the intermediate group. Students from mixed abilities were selected to create a more effective environment for interactions. According to Vygotsky(1978) there are opportunities for students to learn better when they are able to interact with students who are more knowledgeable and competent. He further elaborates that such an environment will be able to develop high mental functions which are related to thinking, problem solving and language.

Students were familiar with the use of Facebook and had access to Internet in school and at home. The teacher participant was an experience teacher and was asked to participate by integrating Facebook for narrative writing over a period of six weeks. The teacher was keen to implement the study and assured that students will be able to acquire some new skills with the use of Facebook for narrative writing. As this is an exploratory study, the researcher did not provide instructions to the teacher.

\subsection{Research Procedures}

Teacher created a closed group discussion in the Facebook environment named Narrative Writing II. Only students who were involved in this study were given the permission to join the group. The students and teacher participated in that closed group. Once the permission to join the group was approved by the researcher, the members started participating in the Facebook environment. The following table indicates the schedule and the use of the Facebook environment for interactions and submission of the essays. Students were guided with materials for Task 1 and 2. For Task 3 students were to work independently as scaffolding was done for Task 1and 2.

Table 1

Schedule of the narrative writing task

\begin{tabular}{lllll}
\hline & $\begin{array}{l}\text { Teacher's } \\
\text { Facebook } \\
\text { environment }\end{array}$ & $\begin{array}{l}\text { Students } \\
\text { Facebook } \\
\text { environment }\end{array}$ & $\begin{array}{l}\text { Students and } \\
\text { Teacher's } \\
\text { Facebook } \\
\text { environment }\end{array}$ & $\begin{array}{l}\text { Students } \\
\text { Facebook } \\
\text { environment }\end{array}$ \\
\hline Week 1-2 & $\begin{array}{l}\text { Title } \\
\text { Material 1 }\end{array}$ & First draft (1) & $\begin{array}{l}\text { social } \\
\text { interaction }\end{array}$ & Final draft (1) \\
\hline Week 3-4 & Title & First Draft (2) & $\begin{array}{l}\text { social } \\
\text { interaction }\end{array}$ & Final draft (2) \\
& Material 2 & First Draft (3) & $\begin{array}{l}\text { social } \\
\text { interaction }\end{array}$ & Final draft (3) \\
\hline Week 5-6 & Title & & & \\
\hline
\end{tabular}


The titles of the narrative writing tasks were:

Task 1: Describe the most embarrassing experience you have had

Task 2: Write a story beginning with "the students were excitedly unloading their luggage"

Task 3: Write a story ending with "tears welled up in his eyes"

\subsection{Data Analysis}

In order to approach the first research question, the essays were marked based on Six Traits Model Assessment Scale by Spandel(2005). The six traits model includes ideas, organization, voice, word choice, sentence fluency and conventions. The model was adapted to suit the Labov and Waletzky's narrative writing structures. Therefore voice aspect was not considered in this study and it is integrated into the organization aspect.

Labov and Waletzky's six structure consists of Abstract, Orientation, Complicating Action, Resolution, Evaluation and Coda which are temporally sequenced The teacher guided the students on Labov and Waletzky's narrative structure. Students were supported with explanation and discussion of the topic. The systematically organized information helps students to write better and increase students' awareness of the criteria for good narrative writing. The structure is illustrated below.

Abstract: What is the story about?

Orientation: Who, when, where, what?

Complicating Action: Then what happened?

Evaluation: So what, how is this interesting?

Result of resolution: What finally happened?

Coda: That's it. I've finished and am "bridging" back to our present situation.

The marking scheme for the essays is summarized in Table 1. The researcher collected the essays and the online archives three times weekly. The researcher met the three raters and explained the marking scheme. Raters were guided to rate a few essays independently to get familiar with the marking scheme and enable to assess the essays given to them accurately. Inter-rater reliability was used to ensure the consistency of the rating system. These sample essays provided a guideline as they were marking the students' assignments. Table 2 illustrates the Model Assessment Scale by Spandel(2005). 
Table 2

Model Assessment Scale by Spandel(2005)

\begin{tabular}{|l|l|l|}
\hline Trait & Scores & Definition \\
\hline Ideas(I) & 20 & $\begin{array}{l}\text { Ideas create the writer's message .They form the thesis or } \\
\text { argument of writing and are supported with details, } \\
\text { examples and anecdotes that inform the reader's } \\
\text { understanding. }\end{array}$ \\
\hline Organization(O) & 20 & $\begin{array}{l}\text { The internal structure that guides the reader smoothly from } \\
\text { beginning to end. Here the writer provides transitions that } \\
\text { guide the reader from one idea to another while paying } \\
\text { attention to the overall logical order of the writing. } \\
\text { Voice }\end{array}$ \\
$\begin{array}{l}\text { This is the persona or presence writes create through their } \\
\text { engagement with their own writing. The writer's own } \\
\text { interest, feelings and reactions to the topic shine through in } \\
\text { the writing, creating a style and expressiveness that } \\
\text { engages the }\end{array}$ \\
\hline Fluency (SF) & 20 & $\begin{array}{l}\text { Reader. This trait is concerned with the rhythm and } \\
\text { cadence the writer produces in the text, a flow of word } \\
\text { structures that engage the reader and make reading more } \\
\text { pleasurable. }\end{array}$ \\
\hline $\begin{array}{l}\text { Word } \\
\text { Choice(WC) }\end{array}$ & 20 & $\begin{array}{l}\text { Choosing the right word at the right time can create just the } \\
\text { mental image or impression the reader needs to understand } \\
\text { the writer's intention. It brings to life the writer's thoughts. }\end{array}$ \\
\hline $\begin{array}{l}\text { Conventions } \\
\text { (Con) }\end{array}$ & 20 & $\begin{array}{l}\text { The mechanics of writing, this trait concerns punctuation, } \\
\text { spelling, grammar and usage and proper paragraphing. }\end{array}$ \\
\hline
\end{tabular}

The quality of the essays was triangulated with the focus group interview. The interview questions were generated based on the essays and their online interactions. All interviews were digitally recorded transcribed and checked by the interviewees for verification. The transcribed interviews were analysed thematically and quotations from the participants were included in this paper.

The data were interpreted based on Creswell's (2009) data analysis and interpretation procedures. The steps were:

Step 1: Organize and prepare the data for analysis

The audio taped interviews were transcribed by the researcher and this gave the opportunity to the researcher to be familiar and fully immersed with the students and teacher's responses.

Step 2: Read through all the data

As soon as the interviews were transcribed, the researcher listened to the audio recordings many times to ensure correct transcriptions. The written transcripts were also read a number of times to make certain what the transcripts were saying.

Step 3: Begin detailed analysis with a coding process 
Coding is described as "the process of segmenting and labelling text to form descriptions and broad themes in the data" (Creswell, 2008, p. 251). Coding takes place when the segments were identified and codes were given to specifically describe the meaning of the text segment (Creswell, 2008). The researcher read the transcripts and identified and grouped the codes. The codes were given numbers.

Step 4: Use the coding process to generate themes for analysis

The themes that appeared from the codes were used to create headings. The various perspectives from students were supported with quotations.

Step 5: Advance how description and themes will be presented in the qualitative nature.

The themes that emerged from the data were written qualitatively to convey the findings of the analysis.

Step 6: Making interpretation of the data.

The researcher compared the findings with previous literature review and theories. By doing so, the researcher was able to confirm past findings or highlight new themes that emerged.

\section{FINDINGS}

\subsection{Narrative Essay Scores}

From the findings it is clear that the writing in the Facebook environment has improved students' narrative writing. Students have gained learning progress, resulted from the use of Facebook for teaching and learning activities. The most prominent improvements were in word choice and sentence fluency. Overall, the scores after the interactions were higher than the scores before the interactions in the Facebook environment. Students exchange of ideas and active participations have improved their writing in certain aspects particularly word choice and sentence fluency. However, scores for organization, ideas and convention were the same before and after their interactions. The scores before and after the interactions are illustrated in Tables 3, 4 and 5.

Table 3

Students' Average Scores for Task 1

\begin{tabular}{|c|c|c|c|c|c|c|c|c|c|c|c|c|}
\hline \multirow{3}{*}{ 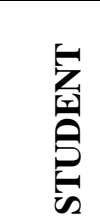 } & \multicolumn{10}{|c|}{ AVERAGE SCORES } & & \\
\hline & \multicolumn{6}{|c|}{ BEFORE INTERACTION } & \multicolumn{6}{|c|}{ AFTER INTERACTION } \\
\hline & $\mathbf{O}$ & I & SF & V & Con & $\mathbf{T}$ & $\mathbf{O}$ & I & SF & V & Con & $\mathbf{T}$ \\
\hline S1 & 15 & 16 & 18 & 11 & 6 & 66 & 15 & 16 & 19 & 12 & 6 & 68 \\
\hline S2 & 14 & 15 & 17 & 13 & 6 & 65 & 14 & 15 & 18 & 15 & 6 & 68 \\
\hline S3 & 15 & 15 & 22 & 15 & 6 & 74 & 15 & 16 & 23 & 16 & 6 & 76 \\
\hline S4 & 14 & 14 & 18 & 13 & 6 & 65 & 14 & 14 & 20 & 15 & 6 & 69 \\
\hline S5 & 14 & 14 & 16 & 14 & 6 & 64 & 14 & 13 & 17 & 16 & 6 & 65 \\
\hline S6 & 17 & 18 & 23 & 16 & 6 & 80 & 17 & 18 & 24 & 17 & 6 & 82 \\
\hline
\end{tabular}

Indonesian Journal of EFL and Linguistics, 2(2), 2017 
Table 4.

Students' Average Scores for Task 2

\begin{tabular}{|c|c|c|c|c|c|c|c|c|c|c|c|c|}
\hline \multirow{3}{*}{$\begin{array}{l}\sum_{\text {空 }} \\
\text { 宣 }\end{array}$} & \multicolumn{10}{|c|}{ AVERAGE SCORES } & & \\
\hline & \multicolumn{6}{|c|}{ BEFORE INTERACTION } & \multicolumn{6}{|c|}{ AFTER INTERACTION } \\
\hline & $\mathbf{O}$ & I & SF & V & Con & $\mathbf{T}$ & $\mathbf{O}$ & I & SF & V & Con & $\mathbf{T}$ \\
\hline S1 & 15 & 16 & 15 & 15 & 6 & 67 & 15 & 16 & 17 & 16 & 6 & 70 \\
\hline S2 & 14 & 15 & 15 & 14 & 6 & 64 & 14 & 15 & 16 & 14 & 6 & 65 \\
\hline S3 & 15 & 15 & 17 & 14 & 6 & 67 & 15 & 15 & 18 & 15 & 6 & 69 \\
\hline S4 & 15 & 16 & 18 & 14 & 6 & 69 & 15 & 16 & 19 & 15 & 6 & 71 \\
\hline S5 & 15 & 16 & 19 & 15 & 6 & 71 & 15 & 15 & 20 & 16 & 7 & 73 \\
\hline S6 & 17 & 18 & 24 & 18 & 6 & 83 & 17 & 18 & 25 & 18 & 6 & 84 \\
\hline
\end{tabular}

Table 5

Students' Average Scores for Task 3

\begin{tabular}{|c|c|c|c|c|c|c|c|c|c|c|c|c|}
\hline \multirow[b]{3}{*}{ 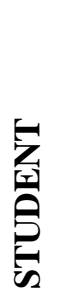 } & \multicolumn{10}{|c|}{ AVERAGE SCORES } & & \\
\hline & \multicolumn{6}{|c|}{ BEFORE INTERACTION } & \multicolumn{6}{|c|}{ AFTER INTERACTION } \\
\hline & $\mathbf{O}$ & I & SF & $\mathbf{V}$ & Con & $\mathbf{T}$ & O & I & SF & $\mathbf{V}$ & Con & $\mathbf{T}$ \\
\hline $\mathrm{S} 1$ & 15 & 15 & 20 & 16 & 7 & 73 & 15 & 15 & 20 & 16 & 7 & 73 \\
\hline S2 & 15 & 15 & 17 & 15 & 7 & 69 & 15 & 15 & 18 & 16 & 7 & 71 \\
\hline S3 & 15 & 14 & 17 & 15 & 7 & 68 & 15 & 15 & 18 & 16 & 7 & 71 \\
\hline S4 & 15 & 15 & 16 & 16 & 7 & 69 & 15 & 15 & 16 & 16 & 7 & 69 \\
\hline S5 & 14 & 15 & 15 & 14 & 7 & 65 & 14 & 15 & 15 & 14 & 7 & 65 \\
\hline S6 & 16 & 18 & 21 & 19 & 7 & 81 & 16 & 18 & 21 & 19 & 7 & 81 \\
\hline
\end{tabular}

\subsection{Narrative Writing}

This section briefly discusses the changes related to organization, ideas, sentence fluency, vocabulary and convention aspects. The organization of the essay was well developed. The student was able to guide the reader with idea and supporting details. For example, in Task 1 one of the students wrote Last Monday I had walk home alone". The supporting details were "The day, the sun shone brightly high up in the azune sky. Beads of sweat dripped down from my cheeks and drenched my school uniform (Catelite Nina). Another student also detailed her ideas by giving supporting details for her idea. The student wrote "My father decided to bring us to the beach. When we heard about the good news, we screamed excitedly. She went on to give more details of the idea by stating that "my elder brother was even jumping on the sofa to express his joy. "(Valentini Belbo).

The logic order of the whole essay is evident in the essay. Since the students were guided by the Labov and Waletzky's narrative structure the students were able to write based on the six elements of narrative structure namely abstract, orientation, 
complicating action, evaluation, resolution and coda. In Task 2, the essay demanded the students to begin their essays with the sentence "The students were excitedly unloading their luggage". As such all the students begin their essays with the sentence and detailed the ideas later. In Task 3, the students basically used flashback techniques presented slightly a different picture in the abstract. Nevertheless, the story was meaningful and coherent till the end. The orientation was also evident as the students detailed the character, place and the events. Some examples of time orientation were "Last Monday" (Valentini Belbo), "Last Sunday" (Catelite Nina). As the narrative essay for Task 1 title demanded them to write about their embarrassing moment, the main character was the writer. In Task 2 and Task 3 a number of characters were introduced. For example, places that were introduced in these essays were Port Dickson beach" (Deer Tommy), "Cameron Highland" (Peony Moon) and "Genting Highlands" (Catelite Nina). In Task 3, the students described the events that took place in a "village" (Catelite Nina), "rainy night" (Peony Moon) and "school" (Moster Kblue).

The conflict and the main problem were introduced by students. Tension and excitement were created with the use of conjunction 'however'. For example, "However we can co-operate very well, at FIRST". In Task 1, the adverb 'suddenly' was used in the essays to indicate the complicating action. For example, "suddenly, a hand put on shoulder" (Valentini Belbo) and "suddenly, I noticed a big shell which was totally" (Catelite Nina). Some examples of evaluation sentences that were related to physical in Task 1 were "I dare to stole a look on the person behind me" (Valentini Belbo), "at the moment I felt like I wanted to find a hole and hide myself " (Catelite Nina) and "I was angry, so I nearly shouted at them". In Task 2, there were examples where the narrator stepped out of the story to tell the readers what the point was "It was only left for one hour" (Valentini Belbo), "they tried many numbers but it was unsuccessful" (Deer Tommy), "when he reached the hall, he was shocked" (Catelite Nina) and "he achieved flying colour results" (Monster Kblue).

The resolution simply indicates the end of the story and provides the outcome of the story (Hatch, 1992). In Task 1, Valentini Belbo wrote that "I stunned, she is my sister" and Deer Tommy wrote "... those boy were taken to the disciplinary room by the disciplinary teacher". In Task 2, the complicating action was resolved when students in their essays wrote "they managed to open the luggage with 1109" (Deer Tommy), "it had indeed gave me a chance to get a piece of mind" (Peony Moon) and "Fortunately, due to the harsh weather condition at that moment the flight was postponed for two hours" (Valentini Belbo). Examples of resolution in Task 3 were "He was flattered by the neighbours concern and love" (Catelite Nina), "Now the little brother started to sob" (Peony Moon) and "he finally got what he wanted" (Monster Kblue). The coda is usually found at the end of the essay. All the six essays in Task 1 used the idea of "embarrassing" or "embarrassing moment" to conclude their essays.

There was adequate use of vocabulary in the essays. However, in some cases, there was inappropriate use of words such as "my friends spotted me curiously" 
(Valentini Belbo) should be 'my friends treated me differently'. The phrases "discipline teacher" (Deer Tommy) should be replaced with 'the disciplinary teacher' and "nutrition food" (Catelite Nina) should be 'nutritious food'. Similar errors were also found in Task 2. Inappropriate use of words was also obvious in Task 2 as the 'opposition team' is termed as "enemies" (Catelite Nina) and "mixed around" (Valentini Belbo) for "mingled around'. Besides, the use of prepositions resulted in errors as in "on the watch" (Valentini Belbo) and "four buses on the trip" (Peony Moon). Errors related to sentence structures were "spent a week's time" (Catelite Nina), "it was only left for one hours" (Valentini Belbo) and "after 2 hours and half" (Peony Moon). In Task 3, a close analysis of the written assignments found the use of idioms which definitely improved the scores for vocabulary. Almost all the students had used idiomatic expressions in their essays. For example, "give a cold shoulder" (Catelite Nina), "turn over a new leaf", "cloud nine" (Monster Kblue), "dust caked layer", "cold atmosphere sent shiver down my spine” (Deer Tommy), "her speech was like dagger piercing John's heart”, "just like throwing cold water" (Valentini Belbo) and "curiosity kills the cat" (Joyce Chee). Additionally, less grammatical mistakes and better sentence structures were found in essays written by students in Task 3. Such instances of improvements were not found in essays written by students for Tasks 1 and 2 .

The raters found that the essays were coherent and fluency is evident when reading the essays A flow of sentence structures and words were engaging the reader and making the reading pleasurable. This is indicated in the scores given for sentence fluency. There were not many changes for the convention aspect as students were able to use the spell check to correct their errors. In order to know why there were no changes in the organization and ideas, the Facebook online archives and materials were analysed. Additionally, simple interview was further conducted to confirm certain findings. It was found that the students strictly followed the Labov and Waletzky's narrative structures. Therefore, there were no changes were made to the ideas and the organization of the essays. In fact the marks were the same before and after the interactions in the Facebook environment.

\subsection{Students' Experiences}

Students attempt to complete their narrative writing tasks suggest that students were interested in using the Facebook environment for narrative writing. A closer and indepth analysis of the interview data has led the researcher to categorize the ideas into several positive and negative emerging themes.

\subsubsection{A convenient writing platform}

Students were eager and approved the Facebook environment as an appropriate platform to improve writing. Various aspects of the writing environment indicating Facebook environment as a convenient writing platform was highlighted by the students. One of the students commented that:

... my friend post a link. I can go and study about it... more information about my grammar and tenses... and then I find out the link post by the teacher. When answer a question it will write out correct or wrong... 
I fail to answer it, so I will post it to the group and ask my friends to help me to solve the questions (Joyce Chee)

The importance of the peers' comments was emphasized. The students reported that "I can look at my friend's essay anytime. Maybe midnight, get to know my mistakes... good one and bad one" (Peony Moon). The platform is considered as a motivating factor by the participants. One of the students confided that her friends essay "is better than me, [mine] so I am proud to have friends like they all" (Deer Tommy). She also highlighted that ".... I want to improve my vocabulary. My friend's essay is good. I wish to be like them” (Deer Tommy).

\subsubsection{Availability of web-resources}

The Facebook environment provided a learning environment that enable students to explore various web-resources. For example, "sometimes use Google translate.com because Chinese words will come out ... so sometimes I use the Google help to translate" (Monster Kblue). Another student recounted "Google translate and dictionary.com.want to double check errors...avoid common errors" (Catelite Nina).

\subsubsection{Engaging Way of Learning}

Participants highlighted that the peers and collaboration work helped them to improve their writing as there were number of valuable suggestions For example, one participant reported that "My friends comments about my essay and I can learn from them" (Valentini Belbo). Another echoed this view stating that "can learning tenses, improve my language, know other people's thought" (Catelite Nina). Acknowledgement of the teachers support was a common theme in the interviews:

-"teacher would highlight our mistake and sometimes ask other members to correct and sometimes she will give me encouragement... ash... share some useful links" (Deer Tommy).

- "the teacher asks us to use uncommon words. Trying to avoid errors on tenses" (Catelite Nina).

- "the teacher ask us reduce grammar mistakes and be more creative for the part of the story line" (Valentini Belbo).

-"she (teacher) commented on my friend's essay and I also want to become like my friend so that she like my essay. So it encourages me" (Monster Kblue).

Such environment increases the sense of caring and emotional connectedness which eventually creates an enjoyable environment for them to complete their narrative writing task. It is evident that the students were having fun while they were engaged in the writing task. The students pointed out that:

- Very fun comment on others' essays and they say thank you, thank you, feel very happy to help them (Joyce Chee)

- I can listen to songs. Find some words to write loh... (Catelite Nina)

- Fun. I think it is fun because I know my friends better (Deer Tommy)

Indonesian Journal of EFL and Linguistics, 2(2), 2017 
When students were asked about their improvements in writing, they said that they had improved in different aspects of writing. For example,

- Vocabulary and story line (Valentini Belbo)

- Spelling, vocabulary (Joyce Chee)

- Idioms and phrasal verbs (Monster Kblue)

- Idioms and other language (Catelite Nina)

\subsubsection{Asynchronous Communication}

There were also frustrating issues related to Facebook. Students expressed their dissatisfaction when there was no immediate feedback for their essays. The particular student felt it was not wise for her to give constructive feedback whereas she was not receiving comments to improve her essays. She expressed her dissatisfaction that "I will comment but my essay only few comments" (Joyce Chee).

\subsubsection{Technological Difficulties}

Technological difficulties have been highlighted by the participant as a barrier to complete their narrative writing task. One of the students expressed her dissatisfaction about time wasted to solve technological problem and how her work has been delayed. In her words "“"my second task when I was typing in my Microsoft word, than I was about to finish, my computer restart. I have to rewrite. No recovery. I feel sad" (Joyce Chee). Another students' frustration was also evident with her statement "the disruptions of the Internet connection make it more difficult" (Joyce Chee). "very lag, very, very slow, then very lazy. It uses up most of my time.

\section{DISCUSSION}

The findings provided evidence that the use of Facebook and the constructivist pedagogical practices to foster students learning is a worthwhile attempt. Thus, the pedagogical break from the tradition classroom to online teaching learning activities can be viewed positively. The finding is consistent with those obtained from by Aydin, 2012; Blanche et al.2013;Manca and Ranieri'(2013) and McCarty (2013) that Facebook is a valuable platform that enhances learning experiences. The study also agrees with the findings of Razak and Saeed (2014) that Facebook can be an effective writing platform with appropriate pedagogical practices. According to Vygotsky(1978) social interactions are central in knowledge construction. In this regard, the result of this study corroborate the ideas highlighted by Vygotsky as interaction, negotiation, peer feedback in the current study has enhanced learning and understanding. Overall, this study adds evidences to support the positive impact of social constructivist theory in the Facebook environment. However, a shift from didactic instruction is necessary as teacher is still dominant in the online environment. Teacher still dominates classroom and students still follow passively without much deep thinking or constructing further knowledge. The instruction has directed the students to follow certain learning style and does not allow them to venture or explore further. The changes made in the essay were very much related to vocabularies and sentence structures. Perhaps teacher should guide students to 
revamp the whole essay as students are not constrained by time and space in the online writing environment. By doing so, students will be engaged in constructing knowledge and not only correcting mistakes that appear in their essays. There is a need to design teaching and learning activities to steer away from online teachercenteredness. In other words, this study suggests that although Facebook can certainly improve students writing by providing interactions and collaboration work, a far more important aspect is how students are facilitated and guided on the subject matter.

The positive experience of students in completing their narrative writing is notable and is a promising in term of implementing online writing via social networking site. Correspondingly, previous research, has reported that social networking sites such as Facebook can be a platform for interaction, collaboration availability of webresources and to overcome time, space and interaction constraints (Mahadi \& Ubaidullah (2010); Weiler (2003) and Papp (2000). These findings are important as there has been lack of research to investigate what influence the success of Facebook in educational context (Manca \&Ranieri, 2013; Kabilan et al. 2010). As such, the findings of this study should be considered valuable in the field of online learning environment. It would be beneficial if students are guided on technical problems. Also pertinent is for all students to comment constructively when they are given an online writing task. It some cases marks should be awarded for constructive comments to encourage students to interact.

\section{LIMITATIONS AND CONCLUSION}

The Facebook as a writing platform integrated into appropriate pedagogical practices shown to be more effective in bolstering writing skills. There are some limitations in this study. Firstly the study is focused on a small group of ESL learners. Therefore more investigation is needed before any definite understanding can be made to these findings. The findings of this study significantly indicate the important of employing social networking sites such as Facebook.The scope of the study was confined to narrative writing and other types of writing should be considered in future. Another aspect that can be considered in future studies will be age, gender, ethnicity and cultural backgrounds.

\section{REFERENCES}

Aydin, S. (2012). A review of research on Facebook as an educational environment. Educational Technology research and development, 60(6), 1093-1106.

Bosch, T. E. (2009). Using online social networking for teaching and learning: Facebook use at the University of Cape Town. Communicatio: South African Journal for Communication Theory and Research, 35(2), 185-200.

Buga, R., Căpeneaţă, I., Chirasnel, C., \& Popa, A. (2014). Facebook in foreign language teaching-A tool to improve communication competences.ProcediaSocial and Behavioral Sciences, 128, 93-98. 
BrotherSoft (2012). Writing Tools. Retrieved 30 December 2012, from http://writing.brothersoft.com/writing-tools.html.

Cantoni, V., Cellario, M., \& Porta, M. (2004). Perspectives and challenges in elearning: towards natural interaction paradigms. Journal of Visual Languages \& Computing, 15(5), 333-345.

Creswell, J. W. (2009). Research Design: Qualitative, quantitative, and mixed methods approaches. Los Angeles: SAGE.

Creswell, J. W. (2008). Educational Research. Planning, conducting and evaluating and qualitative research. New Jersey: Pearson Education

Hamid, S., Waycott, J., Kurnia, S., \& Chang, S. (2014). An empirical study of lecturers' appropriation of social technologies for higher education.Australas $J$ Educ Technol, 30, 295-311.

Hew, K. F. (2011). Students' and teachers' use of Facebook. Computers in Human ehavior, 27(2), 662-676.

Joel, M. M., Ntereke, B., \& Phetlhe, K. R. (2014). Facebook and classroom group work: A trial study involving University of Botswana Advanced Oral Presentation. British Journal of Educational Technology,46(6), 1312-1323

Kabilan, M. K., Ahmad, N., \& Abidin, M. J. Z. (2010). Facebook: An online environment for learning of English in institutions of higher education?. The Internet and higher education, 13(4), 179-187.

Kent, M., \& Leaver, T. (2014). The Revolution That's Already Happening. An education in Facebook, 1-10.

Kwan, G. C. E., \& Skoric, M. M. (2013). Facebook bullying: An extension of battles in school. Computers in Human Behavior, 29(1), 16-25.

Lincoln. Y. S., \& Guba E. G. (1985). Naturalistic inquiry. Newbury Park, CA: Sage.

Mahadi, N., \& Ubaidullah, N. H. (2010). Social Networking Sites: Opportunities for Language Teachers. International Journal of Learning, 17(6).

Lin, T. C., Tsai, C. C., Chai, C. S., \& Lee, M. H. (2013). Identifying science teachers' perceptions of technological pedagogical and content knowledge (TPACK). Journal of Science Education and Technology, 22(3), 325-336.

Manca, S., \& Ranieri, M. (2014). I Social Media vanno all'università? Un'indagine sulle pratiche didattiche degli accademici italiani. Journal of Educational, Cultural and Psychological Studies (ECPS Journal), (10), 305-339.

McCarthy, J. (2015). Learning in the Café: Pilot testing the collaborative application for education in Facebook. Australasian Journal of Educational Technology, 31(1).

Merriam, S. B. (1988). Case study research in education. A qualitative approach.San Francisco: Josey: Bass.

Mehlinger, H. D., \& Powers, S.M. (2002). Technology and teacher education.Boston, New York: Houghton Mifflin Company.

O’Bannon, B. W., Beard, J. L., \& Britt, V. G. (2013). Using a Facebook group as an educational tool: effects on student achievement. Computers in the Schools, 30(3), 229-247. 
Papp, R. (2000). Critical success factors for distance learning. Paper presented at the American Conference on Information System. Long Beach, CA.

Pimmer, C., Linxen, S., \& Gröhbiel, U. (2012). Facebook as a learning tool? A case study on the appropriation of social network sites from mobile phones in developing countries. British Journal of Educational Technology,43(5), 726738.

Razak, N. A., \& Saeed, M. A. (2014). Collaborative writing revision process among learners of English as a foreign language (EFL) in an online community of practice (CoP). Australasian Journal of Educational Technology, 30(5).

Şahin, S., \& Uluyol, Ç. (2016). Preservice Teachers' Perception and Use of Personal Learning Environments (PLEs). The International Review of Research in Open and Distributed Learning, 17(2).

Spandel, V. (2005). Creating writers: Through 6-trait writing assessment and instruction. Allyn \& Bacon.

Staines, Z., \& Lauchs, M. (2013). The use of Facebook in tertiary education: Case study of a unit-related Facebook page in a university justice class. Interactive Technology and Smart Education, 10(4), 285-296.

Selwyn, N. (2009). Faceworking: exploring students' education-related use of Facebook. Learning, Media and Technology, 34(2), 157-174.

Shih, R. C. (2011). Can Web 2.0 technology assist college students in learning English writing? Integrating Facebook and peer assessment with blended learning. Australasian Journal of Educational Technology, 27(5).

Sweeny, S. M. (2010). Writing for the instant messaging and text messaging generation: Using New Literacies to Support Writing Instruction, Journal of Adolescent \& Adult Literacy, 54(2), 121-130.

Vygotsky, L. (1978). Mind in society: The development of higher psychological processes: Cambridge, Mass: Harvard University Press.

Weiler, G. (2003). Using weblogs in the classroom. English Journal, 92(5), 73-75 